\title{
Family functionality and burden of family caregivers of users with mental disorders
}

\author{
Funcionalidade familiar e sobrecarga de familiares cuidadores de usuários com transtornos mentais \\ Funcionalidad familiar y sobrecarga de cuidadores familiares de usuarios con trastornos mentales
}

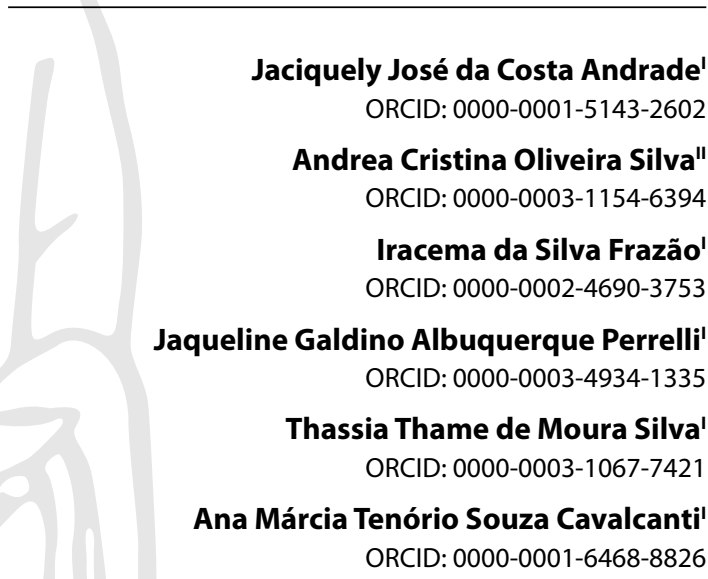

'Universidade Federal de Pernambuco. Recife, Pernambuco, Brazil. "Universidade Federal do Maranhão. São Luis, Maranhão, Brazil.

How to cite this article:

Andrade JJC, Silva ACO, Frazão IS, Perrelli JGA, Silva TTM, Cavalcanti AMTS. Family functionality and burden of family caregivers of users with mental disorders. Rev Bras Enferm. 2021;74(5):e20201061. https://doi.org/10.1590/0034-7167-2020-1061

Corresponding author:

Jaciquely José da Costa Andrade

E-mail: jaciquelyandradeufpe@gmail.com

EDITOR IN CHIEF: Antonio José de Almeida Filho ASSOCIATE EDITOR: Fátima Helena Espírito Santo

Submission: 10-27-2020 Approval: 01-08-2021

\begin{abstract}
Objective: to verify the difference of mean or median in the scores of family functionality and burden of family caregivers of people with mental disorders. Methods: cross-sectional study carried out in a Psychosocial Care Center with 61 family caregivers. Instruments were used for sociodemographic characterization, care process, Family Apgar Index and Family Burden Interview Schedule. Mean/median difference tests were adopted. Results: women with mental disorders and the presence of children in the home decreased the median of the family Apgar score. Difficulty in the relationship between caregiver/user, nervousness/ tension, physical aggression and agitation of patients increased the global average of subjective burden. Conclusions: nursing interventions to reduce burden and promote family functionality should prioritize caregivers of women with mental disorders, assist them in managing troublesome behaviors and raising awareness of family nucleus to co-responsibility for caring for sick people, especially in families with children who demand daily care. Descriptors: Family; Caregivers; Mental disorders; Family Health; Nursing.
\end{abstract}

\section{RESUMO}

Objetivo: verificar a diferença de média ou de mediana nos escores de funcionalidade familiar e de sobrecarga de cuidadores familiares de pessoas com transtorno mental. Métodos: estudo transversal realizado em Centro de Atenção Psicossocial, com 61 cuidadores familiares. Utilizaramse instrumentos para caracterização sociodemográfica, do processo de cuidar, Índice Apgar de Família e Family Burden Interview Schedule. Adotaram-se testes de diferença de média/mediana. Resultados: mulher com transtorno mental e presença de crianças na residência diminuíram a mediana do escore de Apgar familiar. Dificuldade de relacionamento entre cuidador/usuário, nervosismo/tensão, agressividade física e agitação do paciente aumentaram a média global de sobrecarga subjetiva. Conclusões: as intervenções de enfermagem para diminuição da sobrecarga e promoção da funcionalidade familiar devem priorizar cuidadores de mulheres com transtorno mental, auxiliá-los no manejo dos comportamentos problemáticos e sensibilizar o núcleo familiar para a corresponsabilidade pelo cuidado do ente adoecido, sobretudo nas famílias com crianças que demandam cuidados diários.

Descritores: Família; Cuidadores; Transtornos Mentais; Saúde da Família; Enfermagem.

\section{RESUMEN}

Objetivo: verificar la diferencia de media o mediana en las puntuaciones de funcionalidad familiar y sobrecarga de los cuidadores familiares de personas con trastornos mentales. Métodos: estudio transversal realizado en un Centro de Atención Psicosocial, con 61 cuidadores familiares. Se utilizaron instrumentos para la caracterización sociodemográfica, el proceso de cuidado, el Índice de Apgar Familiar y el Family Burden Interview Schedule. Se adoptaron pruebas de diferencia de media/mediana. Resultados: las mujeres con trastornos mentales y la presencia de hijos en el hogar disminuyeron la mediana del Apgar familiar. La dificultad en la relación entre cuidador/usuario, nerviosismo/tensión, agresión física y agitación del paciente aumentaron el promedio global de carga subjetiva. Conclusiones: las intervenciones de enfermería para reducir la carga y promover la funcionalidad familiar deben priorizar a los cuidadores de mujeres con trastornos mentales, asistirlos en el manejo de conductas problemáticas y sensibilizar al núcleo familiar sobre la corresponsabilidad del cuidado del enfermo, especialmente en familias con niños que demandan cuidados diarios. Descriptores: Familia; Cuidadores; Transtornos Mentales; Salud de la Familia; Enfermería. 


\section{INTRODUCTION}

The Brazilian Psychiatric Reform (BPR) and the deinstitutionalization process implementation proposed a new model of mental health care in substitute services within the territory due to the hospital-centered model, with an emphasis on social reintegration and greater family participation in caring for people with mental disorders. Thus, the family context becomes the main environment for the implementation of psychosocial rehabilitation family-based interventions for the construction and execution of the therapeutic project ${ }^{(1-3)}$.

To ensure territorialized health care for people with mental disorders and their families, the Psychosocial Care Network (RAPS - Rede de Atenção Psicossocial) was created by Ordinance 3.088/2011. RAPS consists of the following components: I - primary health care; II - specialized psychosocial care; III - emergency care; IV - transitional residential care; V - hospital care; VI - deinstitutionalization strategies; VII - psychosocial rehabilitation ${ }^{(4)}$.

Among the aforementioned components, primary care (Basic Health Unit - BHU) and specialized psychosocial care (Psychosocial Care Center - CAPS) are the originators of care, guaranteeing a permanent co-management process and longitudinal monitoring of cases ${ }^{(4)}$. In this sense, CAPS are services composed of a multidisciplinary team that works in the extended and shared clinical perspective, articulated to others RAPS provisions, serving people with severe and persistent mental disorders and people with needs resulting from the use of crack, alcohol and other drugs, in their territorial area, in a semi-intensive and non-intensive treatment regime. The activities are carried out primarily in a collective and shared way, articulated with the other points of care of the health network and other networks. Care, within the scope of CAPS, is developed through a Unique Therapeutic Project (PTS - Projeto Terapêutico Singular), which must involve users and their family in the construction process ${ }^{(4)}$.

Family has been considered a strategic care nucleus within the psychosocial care model, with positive impacts, such as breaking the paradigm and prejudices, bringing the family closer to treatment and health services, and, mainly, the reinsertion of people with mental disorders in society, with greater autonomy and respect in the face of social life ${ }^{(5-6)}$.

Significant changes may be necessary in the family organization when taking on the role of participating in the process of caring for people with mental disorders. It is important to highlight that the care model transformation within mental health, with a focus on social reintegration and family participation, still leaves gaps in assistance regarding the community's experience with health services in psychiatry. Sometimes, family members do not feel prepared to take care of their relative in mental distress, a factor that can interfere with family functionality. In this sense, the family nucleus must be trained to deal with changes in the daily routine, troublesome and, eventually, aggressive behaviors, which can cause burden ${ }^{(2,6)}$.

Family functionality is represented by harmonic relationships and the way members of a family relate to each other and to others, with a view to family balance. Thus, the family can be considered functional or dysfunctional ${ }^{(7)}$. A functional or mature family is the one that manages to experience conflicts and critical moments with emotional stability, coexisting harmoniously and independently, maintaining the commitment between its members ${ }^{(7)}$ and therefore plays an important role in caring for people with mental disorders. In dysfunctional or immature family relationships, individual interests are prioritized over the family group. In moments of crisis, family members are blamed for failing to take on their roles within the family environment and have a superficial bond, and may even present aggressive and hostile behaviors ${ }^{(7)}$.

Considering the prominent role played by families in caring for people with mental disorders in the post-psychiatric retirement scenario, there is a need for studies aimed at caregivers of people with mental disorders or psychological distress; especially in developing countries, where there is a greater deficiency of health services aimed at specialized assistance to mentally ill users and their caregivers. The care process can negatively impact the social and professional life of caregivers, their daily routine, relationship with patients, quality of life and cause problems in family functionality due to burden and difficulty in dealing with behaviors inherent to mental disorders ${ }^{(8,12)}$.

Given the above, it is necessary to produce scientific knowledge about the burden of family caregivers, the functioning of families of people with mental disorders and the respective factors related to these phenomena. Such evidence can support nursing interventions in health education aimed at these families, especially for their caregivers, and for the permanent education of professionals who provide daily care for these users, especially nurses.

The role of nurses can improve caregiver's experience through health education, listening and valuing subjects in mental distress ${ }^{(13)}$. Learning about the disease and ways of coping that provide a better quality of life for the family group can reduce the burden that the disease causes in the family context and improve family functioning ${ }^{(13-14)}$.

The hypothesis of this study is that factors of a sociodemographic nature and of the care process are capable of bringing changes in the scores in terms of mean or median, family functionality and burden of family care for people with mental disorders.

\section{OBJECTIVE}

To verify the difference of mean or median in the scores of family functionality and burden of family caregivers of people with mental disorders.

\section{METHOD}

\section{Ethical aspects}

The project was approved by the Human Research Ethics Committee.

\section{Study design, period and place}

This is a cross-sectional study carried out in a CAPS, type II, located in the interior of Pernambuco, Brazil, from April to May 
2019. The research was organized according to the STROBE checklist: cross-sectional studies.

\section{Population or samples; inclusion and exclusion criteria}

The population was composed of family caregivers of people with mental disorders attended at the referred CAPS. As for the sample estimate, it was considered a finite population; $Z_{\alpha}^{2}=1.96$; proportion of occurrence of the phenomenon of interest $=50.0 \%$; sampling error of $10.0 \%(0.01)$. Thus, the sample was estimated at 61 participants. Family caregivers were selected as they met the inclusion criteria: self-declaration of being primary caregivers of CAPS users and being 18 years of age or older. Participants without literacy were interviewed by the responsible researcher, who in turn filled out the research instruments based on the answers given. Family caregivers who had a clinical condition that made it impossible to answer the research instruments were excluded, even with the help of the researcher, and/or received some type of financial remuneration for the care provided that characterized formal caregivers.

\section{Study protocol}

Data were collected through interviews with families of caregivers. The collection took place in a reserved space of the health service in order to guarantee participants' privacy and avoid possible constraints. The following instruments were used for data collection: form for sociodemographic characterization of caregivers (gender, age, marital status, family income, years of study, occupation, type of residence, presence of children in the same household, number of people in the same household); form on the care process elaborated from previous studies ${ }^{(8-12,15-16)}$ (leisure activity, health problem, carrying out treatment for the respective problem, degree of kinship with the person receiving care, length of care, need for help to provide care, help for people with mental disorders in daily activities, troublesome behaviors presented by the family member receiving care, control over the behaviors presented, level of satisfaction in caring, quality of the relationship between family caregiver and person with mental disorders - very $\mathrm{good} / \mathrm{good} / \mathrm{bad}$, and receiving guidance on the relative's illness); APGAR Family Index ${ }^{(15)}$; Family Burden Interview Schedule, version adapted and validated for the Brazilian population (FBIS-BR) ${ }^{(16)}$.

Regarding the behaviors presented by users with mental disorders, those most frequently reported by family caregivers were listed, namely: physical aggression, problems related to sexuality, breaking objects, threats/verbal aggression, continuously demanding attention, agitation, refusing medication, nervousness, poor hygiene, soliloquy, and smoking. Such behaviors were asked to the family members during the interview through the question: what are the behaviors of your family member that bother you the most? Regarding the level of satisfaction in caring, caregivers assessed the quality of the relationship with the family member who receives care through a satisfaction scale, namely: dissatisfied, satisfied, and very satisfied.

The APGAR Family Index assesses family functionality regardless of the life cycle it is in. Its application allows the detection of the presence of family dysfunction, which enables the planning of interventions that favor the reestablishment of balance in the relationships that exist between members of a family ${ }^{(15)}$. This instrument measures satisfaction through five domains: adaptation, partnership, growth, affection, and resolve ${ }^{(15)}$.

Answers are given through the following alternatives: always (2), sometimes (1), and never (0). The results acquired by applying the scale are converted into scores based on the sum of all values obtained in each of the five domains. The total score ranges from 0 to 10 . The sum of the items represents the level of family satisfaction, being: from 0 to 4 (severe family dysfunction), from 5 to 6 (moderate dysfunction) and from 7 to 10 (good functionality) ${ }^{(15,17)}$. The use of this index in primary care has been recommended due to the ability to assess family units and to detect malfunctions in the family system. The translated and validated version for older adults in northeastern Brazil proved to be reliable $(a=0.80)$ and valid for tracking problems related to family functionality ${ }^{(15)}$.

About FBIS - BR, it is a Likert-type scale composed of 70 items, of which 45 refer to the burden assessment presented by family caregivers of users with mental disorders in the last 30 days of living. The scale is organized in two dimensions: objective (21 questions) and subjective (24 questions). Objective burden is assessed using the subscales Assistance to patients in daily life (subscale A), Supervision of patients' troublesome behaviors (subscale B) and Impact on daily routines (subscale $D$ ). As for the subjective burden, we have the subscales: Assistance to patients in daily life (subscale A), Supervision of patients' troublesome behaviors (subscale B) and Concerns about patients by the relative (subscale E). FBIS - BR also has the subscale related to Financial expenses (subscale C), which, although not used in the calculation of the total burden scores, provides additional information regarding the expenses that the family member had with the patient and the weight of this for the family budget ${ }^{(16,18)}$. The instrument showed good psychometric properties for the Brazilian population, with temporal stability and adequate consistency ${ }^{(16,18)}$.

To assess objective burden (subscales A, B and D), the following parameters were used: frequency of assistance and supervision of family members in the daily care of patients and frequency of changes in their life routine. Each item is assessed based on the number of times patients demanded care: 1 - not once; 2 less than once a week; 3 - once or twice a week; 4 - three to six times a week; 5 - every day ${ }^{(16,18)}$. With regard to subjective burden (subscales $A, B, C$ and $E$ ), the following parameters were analyzed: concerns that family members have in relation to patients and level of discomfort caused by the role of caregivers. The responses used to assess relatives' concerns were: 1 - never; 2 - rarely; 3 sometimes; 4 - frequently; 5 - always or almost always. To check the level of discomfort by the role of caregivers, the frequency of the following responses was assessed: 1 - not at all; 2 - very little; 3 - a little; 4 - a lot ${ }^{(16,18)}$. The global objective and subjective burden score was calculated from the means in each subscale related to the respective burden.

\section{Data analysis, and statistics}

The data were typed and stored in a Microsoft ${ }^{\circ}$ Office Excel spreadsheet, version 2016.0, for Windows and exported to the 
SPSS program, version 18.0, for statistical analysis. Initially, a descriptive analysis was performed using absolute and relative frequencies. The numerical variables' normality was tested using the Kolmogorov-Smirnov test. To check associations between sociodemographic variables and the care process, chi-square test or Fisher's exact test were applied according to the observed and expected frequencies. Regarding the verification of the mean/ median difference between FBIS - BR and Family Apgar Index scores between groups, $t$ test for mean difference, Mann-Whitney $U$ test, Median test and Kruskal-Wallis test were used. The significance level of $5.0 \%$ was adopted for analyzing the results.

\section{RESULTS}

Caregivers were, on average, 46.44 years of age ( \pm 16.20 ), with a higher percentage in the age group from 25 to 59 years (adult) $(n=40 ; 65.6 \%)$. The mean of years of study was 7.303 ( \pm 4.817$)$, and only $4.9 \%$ reported more than 15 years of study. As for sex, $52.7 \%(n=32)$ are women, $55.7 \%$ live with a partner $(n=34), 50.8 \%$ receive family income of a minimum wage (R\$998.00, about 181 US dollars) $(n=31)$ and $70.5 \%$ live in their own property $(n=43)$. Approximately $28.0 \%(n=17)$ reported being unemployed, $29.5 \%$ $(n=18)$ were housewives and $19.7 \%(n=12)$ received retirement benefits. The mean of people living in the same house was 3.64. $49.1 \%(n=30)$ live with four to six people in the same residence. Caregivers' most frequent kinship was sister (o) $(n=21 ; 34.4 \%)$ and mother $(n=19 ; 31.1 \%)$.

Regarding the data referring to the process of taking care of people with mental disorders, it was observed that $18.0 \%$ have been caregivers for less than a year, $34.43 \%$, in the range of one to five years, $9.84 \%$, from six to ten years, $9.84 \%$, from 11 to 15 years, $14.75 \%$, from 16 to 20 years and $13.11 \%$, for more than 20 years. Over half of caregivers have some help to care for a sick family member $(n=35 ; 57.4 \%), 62.3 \%$ received guidance on the pathology presented by users $(n=38)$ and $67.2 \%$ reported satisfaction in caring $(n=41)$. Only $6.6 \%(n=4)$ classified the relationship with patients as bad. It was observed that $47.5 \%(n=29)$ of users help with domestic activities and approximately $41.0 \%(n=25)$ receive retirement or benefits due to mental illness. Only $6.55 \%$ $(n=4)$ exercise paid activity.

As for family caregivers' health, all reported having some leisure activity. However, $49.2 \%$ have a health problem $(n=30)$, of which $16.67 \%(n=5)$ do not undergo treatment for the respective problem. Furthermore, $41.0 \%(n=25)$ reported the presence of other people in the family with other illnesses or needs that demand their care and $26.2 \%(n=16)$ reported the presence of children living in the same house. The uncomfortable behaviors presented by patients and most reported by family members who stood out were agitation ( $n=27 ; 44.3 \%)$, nervousness attacks $(n=25 ; 41.0 \%)$, soliloquy ( $n=22 ; 36.1 \%)$, physical aggression $(n=21 ; 34.4 \%)$, and threats/verbal aggression $(n=20 ; 32.8 \%)$.

Concerning family functionality, $65.6 \%(n=40)$ have good family functionality, 9.8\% ( $n=6)$, moderate and $24.6 \%(n=15)$, marked family dysfunction. The mean global family Apgar score was $6.79( \pm 2.835)$, and this measure did not show adherence to the standard normal distribution ( $p<0.001$ - Kolmogorov-Smirnov test). Thus, the median analyzes were carried out to verify whether the sociodemographic variables and the care process caused any change in this score (Table 2 ). Women with mental disorders had lower family Apgar scores in terms of median and average rank, compared to male patients. Decrease in this score was also evidenced in the presence of children in the same residence. The other sociodemographic variables, the care process and the burden did not cause changes in the median of this index.

Concerning caregiver objective burden, supervising the family member when taking medications was the activity that caused the greatest objective burden on caregivers. Comparatively, taking responsibility for patients' purchases determined a lower level of objective burden felt by family members.

Table 1 - Difference in the mean of the family Apgar score according to variables in the care process, Vitoria de Santo Antão, Pernambuco, Brazil, 2019

\begin{tabular}{|c|c|c|c|c|c|}
\hline Variables & $\mathbf{n}$ & $\%$ & Median & $\begin{array}{l}\text { Medium } \\
\text { Post }\end{array}$ & $p$ value \\
\hline \multicolumn{6}{|c|}{$\begin{array}{l}\text { Woman with mental } \\
\text { disorders }\end{array}$} \\
\hline Yes & 29 & 47.5 & 7.00 & 23.88 & $0.016^{*}$ \\
\hline No & 32 & 52.5 & 8.50 & 37.45 & $0.003^{* *}$ \\
\hline \multicolumn{6}{|c|}{$\begin{array}{l}\text { Presence of children in } \\
\text { the same residence }\end{array}$} \\
\hline Yes & 16 & 26.2 & 4.50 & 18.78 & $0.014^{*}$ \\
\hline No & 45 & 73.8 & 8.00 & 35.34 & $<0.001 * *$ \\
\hline
\end{tabular}

Regarding subjective burden, it was observed that most family caregivers did not feel high subjective burden when providing Assistance to patients in daily life (subscale A). On the other hand, there was a high degree of subjective burden in the supervision of troublesome behaviors (subscale B), in which dealing with such behaviors and night disturbance were the items with the highest burden in this subscale. The items concern for the future, finances and the health of people with mental disorders generated a high subjective burden on caregivers with regard to subscale $E$ (Concern about patients). Furthermore, over half of family members showed a high subjective burden related to subscale $C$ (Financial expenses). Further details are described in Table 2.

Regarding the global burden score (Table 3), it is observed that subscales $A$ and $E$ presented, respectively, a greater mean of objective and subjective burden among the other subscales.

In terms of difference in mean and median of subjective burden scores and their respective subscales, as shown in Table 4 , it was demonstrated that relationship difficulties between caregiver and patient, nervousness/tension of patients, physical aggression and agitation increased the global mean subjective burden. Regarding the differences in median burden, caregivers whose patients are women, with children in the same residence, with an unsatisfactory relationship with sick people, who need to deal with refusal of medication, nervousness/tension and poor hygiene of patients had higher average positions subscale $A$ (Assistance to patients in daily life) in the subjective dimension. As for subscale E - subjective, physical aggression, agitation and nervousness/tension contributed significantly to the increase in the mean of this subscale. The other sociodemographic variables, the care process and family functionality did not cause changes of mean or median in caregiver subjective burden. 
Table 2 - Degree of objective and subjective burden of family caregivers of people with mental disorders according to the Family Burden Interview Schedule (FBIS-BR) Scale, Vitoria de Santo Antão, Pernambuco, Brazil, 2019

\begin{tabular}{|c|c|c|c|c|c|}
\hline \multirow[b]{2}{*}{ Subscales } & \multirow[b]{2}{*}{ Items } & \multicolumn{2}{|c|}{ Objective } & \multicolumn{2}{|c|}{ Subjective } \\
\hline & & $\begin{array}{c}\text { Low } \\
\% \\
1 \\
\text { and } 2^{1}\end{array}$ & $\begin{array}{l}\text { High } \\
\% \\
4 \\
\text { and } 5^{2}\end{array}$ & $\begin{array}{c}\text { Low } \\
\% \\
1 \\
\text { and } 2^{3}\end{array}$ & $\begin{array}{l}\text { High } \\
\% \\
3 \text { and } 4^{4} / \\
4 \text { and } 5^{5}\end{array}$ \\
\hline $\begin{array}{l}\text { A: Assistance } \\
\text { to patients in } \\
\text { daily life }\end{array}$ & $\begin{array}{l}\text { Hygiene } \\
\text { Medication } \\
\text { House chores } \\
\text { Purchases } \\
\text { Food } \\
\text { Transportation } \\
\text { Money } \\
\text { Time occupation } \\
\text { Medical consultation }\end{array}$ & $\begin{array}{l}41.0 \\
24.6 \\
45.9 \\
67.2 \\
27.8 \\
29.5 \\
62.3 \\
36.1 \\
42.6\end{array}$ & $\begin{array}{l}54.1 \\
65.6 \\
50.8 \\
16.4 \\
55.7 \\
36.1 \\
29.5 \\
54.1 \\
27.9\end{array}$ & $\begin{array}{l}52.7 \\
68.8 \\
60.6 \\
85.2 \\
91.1 \\
90.0 \\
90.6 \\
79.4 \\
86.6\end{array}$ & $\begin{array}{c}47.3 \\
31.2 \\
39.4 \\
14.8 \\
8.9 \\
10.0 \\
9.4 \\
20.6 \\
13.4\end{array}$ \\
\hline $\begin{array}{l}\text { B: Supervision } \\
\text { of patients' } \\
\text { troublesome } \\
\text { behaviors }\end{array}$ & $\begin{array}{l}\text { Troublesome behaviors } \\
\text { Asking for excessive attention } \\
\text { Night disturbance } \\
\text { Hetero-aggression } \\
\text { Self-harm } \\
\text { Smoking or drinking too much (soft drinks) }\end{array}$ & $\begin{array}{l}59.0 \\
60.7 \\
72.2 \\
68.8 \\
65.6 \\
67.2\end{array}$ & $\begin{array}{l}27.9 \\
27.8 \\
23.0 \\
13.2 \\
18.0 \\
22.9\end{array}$ & $\begin{array}{c}16.2 \\
32.0 \\
23.8 \\
36.0 \\
0.0 \\
36.3\end{array}$ & $\begin{array}{l}83.8 \\
68.0 \\
76.2 \\
64.0 \\
37.7 \\
63.7\end{array}$ \\
\hline C: Expenses & Weight of patient expenses & - & - & 31.1 & 55.7 \\
\hline $\begin{array}{l}\text { D: Impact on } \\
\text { caregivers'lives }\end{array}$ & $\begin{array}{l}\text { Delays or absences from appointments } \\
\text { Changes in caregiver leisure } \\
\text { Changes in home service/routine } \\
\text { Decreased attention to other family members }\end{array}$ & $\begin{array}{l}42.6 \\
37.7 \\
59.0 \\
44.2\end{array}$ & $\begin{array}{l}23.0 \\
37.7 \\
24.6 \\
22.9\end{array}$ & $\begin{array}{l}- \\
- \\
-\end{array}$ & $\begin{array}{l}- \\
- \\
-\end{array}$ \\
\hline $\begin{array}{l}\text { E: Concern about } \\
\text { patients }\end{array}$ & $\begin{array}{l}\text { Physical security } \\
\text { Quality of treatment } \\
\text { Social life } \\
\text { Health } \\
\text { Housing } \\
\text { Finances } \\
\text { Future }\end{array}$ & $\begin{array}{l}- \\
- \\
- \\
- \\
- \\
-\end{array}$ & $\begin{array}{l}- \\
- \\
- \\
- \\
- \\
-\end{array}$ & $\begin{array}{c}8.0 \\
51.6 \\
24.2 \\
9.7 \\
56.5 \\
4.8 \\
1.6\end{array}$ & $\begin{array}{l}22.9 \\
30.7 \\
61.3 \\
79.1 \\
32.2 \\
80.7 \\
93.6\end{array}$ \\
\hline
\end{tabular}

Objective burden: ${ }^{1} 1$ and 2: Not once/less than once a week; ${ }^{2} 4$ and $5:$ three to six times a week/every day. Subjective burden: ${ }^{3}$ subscales A and B: 1 - Not at all/2 - very little; ${ }^{3}$ subscales C and E: 1 - Never $/ 2$ - rarely; ${ }^{3}$ subscale D: 1 - Not once/2 - less than once a week; ${ }^{4}$ subscales $A, B$ and D: 3 - a little/4 - a lot; ${ }^{4}$ subscale C: 3 - Sometimes; ${ }^{5}$ subscales $C$ and $E: 4$ - Often/5 - Always or almost always.

Table 3 - Distribution of the means of global objective and subjective burden scores and their respective subscales according to the Family Burden Interview Schedule (FBIS-BR) Scale, Vitória de Santo Antão, Pernambuco, Brazil, 2019

\begin{tabular}{llccc}
\hline Subscales & Dimensions & Mean & Median & $\boldsymbol{p}$ value* \\
\hline A: Assistance to patients in daily life & Objective & $2.989( \pm 0.850)$ & 2.889 & 0.200 \\
& Subjective & $1.107( \pm 0.717)$ & 1.000 & $<\mathbf{0 . 0 0 1}$ \\
B: Supervision of troublesome & Objective & $2.068( \pm 0.887)$ & 2.000 & 0.046 \\
behaviors & Subjective & $1.216( \pm 0.981)$ & 1.167 & 0.016 \\
D: Impact on routine & Objective & $2.451( \pm 1.193)$ & 2.000 & $<\mathbf{0 . 0 0 1}$ \\
E: Concerns about patients & Subjective & $3.850( \pm 0.692)$ & 3.857 & 0.200 \\
Overall objective burden score & -- & $2.503( \pm 0.805)$ & 2.287 & 0.048 \\
Overall subjective burden score & -- & $2.058( \pm 0.577)$ & 1.976 & 0.200 \\
\hline
\end{tabular}

*Kolmogorov-Smirnov test (normality).

Table 4 - Difference of mean and median of subjective burden scores and their respective subscales $\mathrm{A}$ and $\mathrm{E}$ between groups of sociodemographic variables and the care process, Vitória de Santo Antão, Pernambuco, Brazil, 2019

\begin{tabular}{lccccc}
\hline Variables & $\mathbf{n}$ & \% & Mean & SD & $\boldsymbol{p}$ value \\
\hline Subjective burden & & & & & \\
$\quad$ Relationship with patients & & & & & \\
$\quad$ Unsatisfactory & 4 & 6.55 & 3.557 & 0.403 & \\
$\quad$ Satisfactory & 37 & 60.65 & 2.775 & 0.617 & $0.002^{*}$ \\
$\quad$ Very satisfactory & 20 & 32.80 & 2.349 & 0.671 & \\
\hline
\end{tabular}

Among the variables related to the care process. the troublesome behaviors presented by patients caused changes in caregiver objective burden. Thus, threats/verbal aggression, nervousness/tension and soliloquy significantly increased the mean of subscale $A$ objective. For subscale B - objective, the presence of other sick people in the same residence that demand care, behavior of breaking objects, nervousness of patients and soliloquy increased the medians of that subscale and subscale D - objective. Sociodemographic variables and family functionality did not cause changes in mean or median in caregiver objective burden. Further details are contained in Table 5.

\section{DISCUSSION}

Care after psychiatric hospitalization or community-based treatment is. in most cases, taken on by women, who share this time with activities aimed at the care of their own children, husband and domestic activities ${ }^{(19)}$; this corroborates the findings of this study, in which female caregivers, married, unemployed, housewives, with low educational level prevailed who need to play the role of caregiver in addition to other activities of daily living, which reinforces the social construction of the female role exercising this function ${ }^{(20)}$. The historical process is determinant of this reality, since care is an activity related to women since the beginning. There is also the female vulnerability that, even in large families, care is still exercised by a single person, contributing to their burden, compromising self-care and increasing the risk of illness ${ }^{(5,21-22)}$.

Regarding family functionality, it was found that more than half of caregivers had good family functionality. The satisfactory bond between family members and good family functionality improve care provision to sick people. Healthy emotional involvement among family members generates positive feelings and a better relationship, in addition to changing the sense of burden that the responsibility and obligation of care can entail. This satisfactory family relationship can help to reduce the burden levels, favoring the positive 


\begin{tabular}{|c|c|c|c|c|c|}
\hline Variables & $\mathbf{n}$ & $\%$ & Mean & SD & $p$ value \\
\hline \multicolumn{6}{|l|}{ Nervousness/tension } \\
\hline Yes & 25 & 40.99 & 2.989 & 0.639 & \multirow{2}{*}{$0.003^{* *}$} \\
\hline No & 36 & 59.01 & 2.476 & 0.646 & \\
\hline \multicolumn{6}{|c|}{ Physical aggressiveness } \\
\hline Yes & 21 & 34.40 & 2.967 & 0.622 & \multirow[t]{2}{*}{$0.017^{* *}$} \\
\hline No & 40 & 65.60 & 2.539 & 0.680 & \\
\hline \multicolumn{6}{|l|}{ Agitation } \\
\hline Yes & 27 & 44.30 & 2.937 & 0.700 & \multirow[t]{2}{*}{$0.011^{* *}$} \\
\hline No & 34 & 55.70 & 2.487 & 0.616 & \\
\hline \multicolumn{6}{|l|}{ Subscale A - Subjective } \\
\hline Caregiver sex & & & & & \multirow{3}{*}{$0.013^{* * *}$} \\
\hline Women & 45 & 73.78 & 1.826 & 0.125 & \\
\hline Men & 16 & 26.22 & 1.270 & 0.101 & \\
\hline \multicolumn{6}{|c|}{ Presence of children at home } \\
\hline Yes & 16 & 26.22 & 2.028 & 0.232 & \multirow[t]{2}{*}{$0.049 * * *$} \\
\hline No & 45 & 73.78 & 1.556 & 0.104 & \\
\hline \multicolumn{6}{|c|}{ Relationship with patients } \\
\hline Unsatisfactory & 4 & 6.55 & 2.750 & 0.479 & \multirow[t]{3}{*}{$<0.001 * * * * *$} \\
\hline Satisfactory & 37 & 60.65 & 1.760 & 0.109 & \\
\hline Very satisfactory & 20 & 32.80 & 1.319 & 0.170 & \\
\hline \multicolumn{6}{|l|}{ Refusing medication } \\
\hline Yes & 14 & 22.95 & 2.083 & 0.232 & $0.029^{* * *}$ \\
\hline No & 47 & 77.05 & 1.560 & 0.106 & $0.019^{* * * *}$ \\
\hline \multicolumn{6}{|l|}{ Nervousness/tension } \\
\hline Yes & 25 & 40.99 & 2.000 & 0.184 & \multirow[t]{2}{*}{$0.014^{* * *}$} \\
\hline No & 36 & 59.01 & 1.458 & 0.099 & \\
\hline \multicolumn{6}{|l|}{ Lack of hygiene } \\
\hline Yes & 18 & 29.50 & 2.115 & 0.229 & \multirow{2}{*}{$\begin{array}{c}0.013^{* * * *} \\
0.027^{* * * * *}\end{array}$} \\
\hline No & 43 & 70.50 & 1.498 & 0.094 & \\
\hline \multicolumn{6}{|l|}{ Subscale E - Subjective } \\
\hline Physical aggressiver & & & & & \multirow{3}{*}{$0.004^{* *}$} \\
\hline Yes & 21 & 34.40 & 4.197 & 0.641 & \\
\hline No & 40 & 65.60 & 3.668 & 0.654 & \\
\hline \multicolumn{6}{|l|}{ Agitation } \\
\hline Yes & 27 & 44.30 & 4.048 & 0.626 & \multirow[t]{2}{*}{$0.043^{* *}$} \\
\hline No & 34 & 55.70 & 3.693 & 0.710 & \\
\hline \multicolumn{6}{|l|}{ Nervousness/tension } \\
\hline Yes & 25 & 40.99 & 4.063 & 0.640 & \multirow[t]{2}{*}{$0.042^{* *}$} \\
\hline No & 36 & 59.01 & 3.702 & 0.697 & \\
\hline
\end{tabular}

*ANOVA test; ${ }^{* *}$ T test; ${ }^{* * *}$ Mann-Whitney $U$ test; ${ }^{* * * *}$ Median test; ${ }^{* * * * * K r u s k a l-W a l l i s ~ t e s t . ~}$

Table 5 - Difference in mean and median of objective burden scores and their respective subscales B and $\mathrm{D}$ according to the troublesome behaviors presented by people with mental disorders, Vitória de Santo Antão, Pernambuco, Brazil, 2019

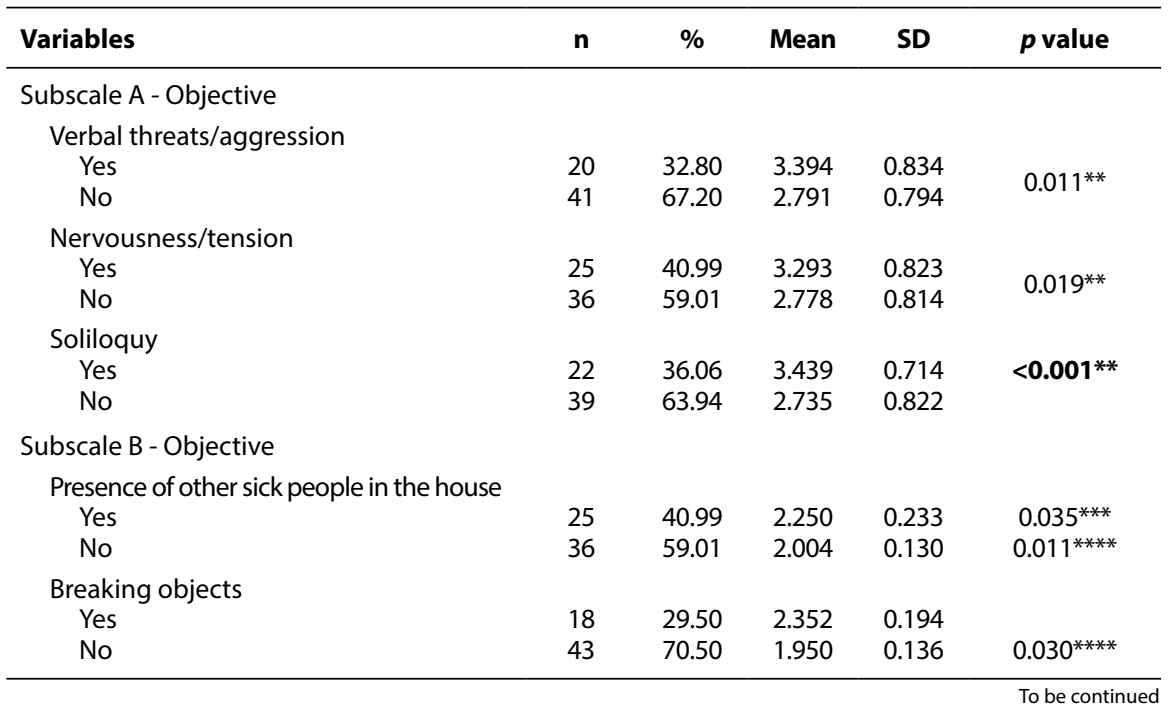

feeling in relation to the care provided to people in mental distress by their relatives $^{(14)}$. Furthermore, support for family members who exercise the role of caregiver and the division of responsibility for care improves quality of life, decreasing their chances of becoming ill and the mental burden associated with the role of caregivers ${ }^{(14)}$.

Still on the family Apgar, women with mental disorders and the presence of children in the same household resulted in a lower score in this index, that is, less family functionality. Mental illness sometimes impairs self-care, attention to others, causing changes in the daily routine. Furthermore, the involvement of women with a mental disorder requires care shared by the whole family, which does not always occur, causing collective losses and family functioning ${ }^{(23)}$. Moreover, women play the role of mother, sometimes without adequate family and social support, which can contribute to woman caregiver burden and, consequently, problems in family functioning. Therefore, it is necessary for all family members to develop skills related to the assistance provided to people with mental disorders in daily activities and resocialization, especially in the presence of children who need concomitant care, since this role is not only for women ${ }^{(21)}$.

Although this study did not show the relationship between family functionality and burden, authors state that some families have difficulties in meeting the care needs of one of their members due to several factors, among which the relational ones stand out. Taking on the role of caregiver causes changes, sometimes negative, in life projects, daily routine of families, compromises leisure, increasing the family's responsibility for sick people, which can generate a feeling of burden to be carried and/or problems in family functioning. Living in a dysfunctional family can lead to mental suffering, isolation or worsening of the illness ${ }^{(24)}$.

Specifically about the burden, taking responsibility for patients' medication was the activity that caused the greatest objective burden. Troubled behaviors, tasks related to patient 
Table 5 (concluded)

\begin{tabular}{|c|c|c|c|c|c|}
\hline Variables & $\mathbf{n}$ & $\%$ & Mean & SD & $p$ value \\
\hline \multicolumn{6}{|c|}{ Nervousness/tension } \\
\hline Yes & 25 & 40.99 & 2.307 & 0.186 & \\
\hline No & 36 & 59.01 & 1.903 & 0.138 & $0.043^{* * * *}$ \\
\hline \multicolumn{6}{|c|}{ Subscale D - Objective } \\
\hline \multicolumn{6}{|c|}{ Breaking objects } \\
\hline Yes & 18 & 29.50 & 2.861 & 0.264 & \\
\hline No & 43 & 70.50 & 2.279 & 0.182 & $0.041^{* * * *}$ \\
\hline \multicolumn{6}{|c|}{ Nervousness/tension } \\
\hline Yes & 25 & 40.99 & 2.890 & 0.261 & $0.025^{* * *}$ \\
\hline No & 36 & 59.01 & 2.146 & 0.170 & \\
\hline \multicolumn{6}{|c|}{ Soliloquy } \\
\hline Yes & 22 & 36.06 & 3.068 & 0.245 & $0.002^{* * *}$ \\
\hline No & 39 & 63.94 & 2.103 & 0.173 & $0.013^{* * * *}$ \\
\hline
\end{tabular}

hygiene, night disturbance, concern about the future, finances and health of sick people were responsible for generating subjective high burden on caregivers. It is also noteworthy that the mean and median of the family burden score were substantially influenced by sick people's troublesome behaviors.

A research of 82 caregivers of children or adolescents with mental disorders showed an objective high burden regarding assistance in activities of daily living, such as supervision of medication taking and high subjective burden regarding supervision of troublesome behaviors ${ }^{(25)}$. Another investigation with caregivers of family members with mental disorders at CAPS and a psychiatric hospital showed greater burden regarding Supervision of patients' troublesome behaviors and the impact on daily routines, greater objective burden regarding Assistance to patients in daily life, which is uncomfortable when supervising troublesome behaviors and greater concern for the future ${ }^{(26)}$. For some authors, excess of concern and overprotection in the care process interferes with privacy and compromises the subject's autonomy, in addition to promoting subjective high burden related to the feeling of concern of relatives with their relatives under treatment ${ }^{(27)}$.

Non-adherence to pharmacological treatment favors the aggravation of signs and symptoms of mental disorder, increases the risk of frequent hospitalizations and suicide of people with mental disorders. Thus, such problems can cause greater burden for caregivers for requiring greater monitoring of medication use, even in users who accept the medication ${ }^{(28)}$. The presence of positive, negative and/or cognitive symptoms tends to increase the burden of caregivers who expend more energy to compensate and/or understand the reasons for troublesome behaviors than in overcoming them or the symptoms presented by the person with mental disorder ${ }^{(29)}$. Additionally, it should be noted that sleep disorders, found in this study, also have a substantially negative impact on the functioning and well-being of users and caregivers ${ }^{(30)}$. Insomnia specifically contributes significantly to the worsening of delirium and hallucinations in people with schizophrenia ${ }^{(31-33)}$, increases the chance of recurrence of depression ${ }^{(34)}$, suicidal ideation and attempted suicide ${ }^{(35)}$. In the caregiver context, burden, stress and vulnerability to chronic diseases are accentuated ${ }^{(36-38)}$.

Authors state that insomnia can be a causal factor of mental illness or a symptom of illness installed. Thus, they recommend early assessment of sleep disorders in people with mental disorders, whose treatment can have a positive impact on the prognosis of

\section{Study limitations}

The limitations include a small sample size, selection of participants in a non-probabilistic manner and execution of the study at only one CAPS. Thus, it is suggested to carry out similar research with larger samples of users and family members of other CAPS in order to avoid possible biases.

\section{Contributions to nursing, health, and public policy}

The changes in the mental health nurses' work process, after BPR, aim at a professional who not only promotes the repetition of techniques, but has a holistic view that considers the individuality of the human being, interpersonal relationships and living with the family, with a view to self-care and subject empowerment. The study provides evidence on factors that led to changes in family Apgar scores and burden such as: women with mental disorders and the presence of children in the same household (family Apgar); relationship difficulties between caregiver/patient; behaviors presented by the person with mental disorder (burden) that may subsidize nursing interventions to assist family members in the process of caring for people with mental disorder.

\section{CONCLUSION}

Regarding family functionality, over half of caregivers had good family functionality. Women with mental disorders and the presence of children at home caused statistically significant changes in the median of the family Apgar score. No relationship was found between family functionality and caregiver burden.

Regarding the global score of objective and subjective burden, subscales $A$ and E presented, respectively, a greater mean of objective and subjective burden. In terms of difference in mean, it was demonstrated that difficulty in the relationship between caregiver and patient, nervousness/tension of patients, physical aggression and agitation increased the global mean of subjective burden. The troublesome behaviors presented by patients, such as physical aggression, threats/verbal aggression, refusing medication and lack of hygiene, significantly increased the mean of subscale $A$ - objective and $E$ - subjective, in addition to increasing dissatisfaction with caring for people with mental disorders. Furthermore, it was evidenced that family members 
who care for women with mental disorders, children in the same residence, unsatisfactory relationship with sick people who need to deal with refusal of medication, nervousness/tension and poor hygiene of patients presented greater subjective burden related to Assistance to patients in daily life (subscale A).

It is recommended that family members responsible for caring for people with mental disorders receive differentiated attention by mental health services, especially nurses, in order to support them in their demands through qualified listening and mediation of family conflicts, aiming at a better distribution of domestic chores and reducing their burden through the co-responsibility of other family members for caring for sick people.

\section{SUPPEMENTARY MATERIAL}

This article originates from the master's thesis entitled "Funcionalidade familiar e sobrecarga de familiares cuidadores de pessoas com transtorno mental", available from: https://repositorio.ufpe.br/ bitstream/123456789/38292/1/DISSERTA\%C3\%87\%C3\%830\%20 Jaciquely\%20Jos\%C3\%A9\%20da\%20Costa\%20Andrade.pdf

\section{FUNDING}

The research was funded by the Coordination for the Improvement of Higher Education Personnel (CAPES - Coordenação de Aperfeiçoamento de Pessoal de Nível Superior).

\section{REFERENCES}

1. Porto LFA, Bandeira M, Oliveira M. Sobrecarga de familiares cuidadores de pacientes psiquiátricos: relação com a resiliência. Interação Psicol. 2019;23(3):346-56. https://doi.org/10.5380/psi.v23i3.56750

2. Martins PPS, Guanaes-Lorenzi C. Participação da família no tratamento em saúde mental como prática no cotidiano do serviço. Psicol Teor Pesqui. 2016;32(4):e324216. https://doi.org/10.1590/0102.3772e324216

3. Baptista JA, Camatta MW, Filippon PG, Schneider JF. Projeto terapêutico singular na saúde mental: uma revisão integrativa. Rev Bras Enferm. 2020;73(2):e20180508. https://doi.org/10.1590/0034-7167-2018-0508

4. Ministério da Saúde (BR). Portaria no. 3.088, de 23 de dezembro de 2011. Institui a Rede de Atenção Psicossocial para pessoas com sofrimento ou transtorno mental e com necessidades decorrentes do uso de crack, álcool e outras drogas, no âmbito do Sistema Único de Saúde (SUS). Diário Oficial da União 30 de dezembro de 2011; Seção 1.

5. Bezerra KMG, Leandro ACC, Brito MGJP, Oliveira SRPB, Silva TTM, Frazão IS. Repercussions of Mental Disorders in the family context. AJPRR [Internet]. 2020 [cited 2020 Aug 25];3(14). Available from: https://escipub.com/Articles/AJPRR/AJPRR-2020-02-0905.pdf

6. Salles MM, Barros S, Santos JC. Family relationships of people with mental health problems: processes of social exclusion and inclusion Rev Enferm UERJ. 2019;27:e26923. https://doi.org/10.12957/reuerj.2019.26923

7. Souza RA, Costa GD, Yamashita CH, Amendola F, Gaspar JC, Alvarenga MRM, et al. Funcionalidade familiar de idosos com sintomas depressivos. Rev Esc Enferm USP. 2014;48(3):469-76. https://doi.org/10.1590/S0080-623420140000300012

8. Ae-Ngibise KA, Doku VC, Asante KP, Owusu-Agyei S. The experience of caregivers of people living with serious mental disorders: a study from rural Ghana. Glob Health Action. 2015;8:26957. https://doi.org/10.3402/gha.v8.26957

9. Oliveira EM. Cordeiro ESM, Lima D, Linhares AMF. Family needs a break: it takes care of people with mental disorder. Rev Pesqui: Cuid Fundam. 2017;9(1):71-8. https://doi.org/10.9789/2175-5361.2017.v9i1.71-78

10. Batista $\mathrm{CF}$, Bandeira $\mathrm{M}$, Oliveira DR. Fatores associados à sobrecarga subjetiva de homens e mulheres cuidadores de pacientes psiquiátricos. Ciênc Saúde Coletiva. 2015;20(9):2857-66. https://doi.org/10.1590/1413-81232015209.03522014

11. Kizilimark B, Kuçuk L. Care burden level and mental health condition of the families of individuals with mental disorders. Arch Psychiatr Nurs. 2016;30:47-54. https://doi.org/10.1016/j.apnu.2015.10.004

12. Campana MC, Soares MH. Familiares de pessoas com esquizofrenia: sentimentos e atitudes frente ao comportamento agressivo. Cogitare Enferm [Internet]. 2015 [cited 2020 Dec 29];20(2):338-44. Available from: https://docs.bvsalud.org/biblioref/2016/08/1266/40374-157249-1-pb.pdf

13. Braga FS, Olschowsky A, Wetzel C, Silva AB, Nunes CK, Botega MSX. Nurse's means of work in the articulation of the psychosocial care network. Rev Gaúcha Enferm. 2020;41(spe):e20190160. https://doi.org/10.1590/1983-1447.2020.20190160

14. Gomes MLP, Silva JCB, Batista EC. Escutando quem cuida: quando o cuidado afeta a saúde do cuidador em saúde mental. Rev Psicol Saúde. 2018;10(1):3-7. https://doi.org/10.20435/pssa.v10i1.530

15. Silva MJ, Victor JF, Mota FRN, Soares ES, Leite BMB, Oliveira ET. Analysis of psychometric properties of family APGAR with elderly in northeast Brazil. Esc Anna Nery. 2014;18(3):527-32. https://doi.org/10.5935/1414-8145.20140075

16. Bandeira M, Calzavara MGP, Castro I. Estudo de validade da escala de sobrecarga de familiares cuidadores de pacientes psiquiátricos. J Bras Psiquiatr. 2008;57(2):98-104. https://doi.org/10.1590/S0047-2085200800020000313

17. Vera I, Lucchese R, Munari DB, Nakatani AYK. Índex APGAR de Família na avaliação de relações familiares do idoso: revisão integrativa. Rev Eletr Enf. 2014;16(1):199-210. https://doi.org/10.5216/ree.v16i1.22514

18. Bandeira M, Calzavara MGP, Freitas LC, Barroso SM. Family Burden Interview Scale for relatives of psychiatric patients (FBIS-BR): reliability study of the Brazilian version. Rev Bras Psiquiatr. 2007;29(1):47-50. https://doi.org/10.1590/S1516-44462006005000015 
19. Souza ALR, Guimarães RA, Araújo Vilela D, Assis RM, Oliveira LMDAC, Souza MR, et al. Factors associated with the burden of family caregivers of patients with mental disorders: a cross-sectional study. BMC Psychiatr. 2017;17(1):353. https://doi.org/10.1186/s12888-017-1501-1

20. Loureiro LSN, Fernandes MGM. Profile of the family caregiver of dependent elderly in home living. Rev Pesq Cuid Fundam. 2015;7(5):145-54. https://doi.org/10.9789/2175-5361.2015.v7i5.145-154

21. Reis TL, DahI CM, Barbosa SM, Teixeira MR, Delgado PGG. Burden and participation of family in the care of Psychosocial Care Centers users. Saúde Debate. 2016;40(109):70-85. https://doi.org/10.1590/0103-1104201610906

22. Alves JFM, Almeida AL, Mata MAP, Pimentel MH. Problemas dos cuidadores de doentes com esquizofrenia: a sobrecarga familiar. Rev Port Enferm Saúde Mental. 2018;(19):8-16. https://doi.org/10.19131/rpesm.0197

23. Senicato C, Azevedo RCS, Barros MBA. Common mental disorders in adult women: identifying the most vulnerable segments. Ciênc Saúde Colet. 2018;23(8):2543-2554. https://doi.org/10.1590/1413-81232018238.13652016

24. Ramos AC, Calais SL, Zotesso MC. Convivência do familiar cuidador junto a pessoa com transtorno mental. Contextos Clínic. 2019;12(1):282302. https:// doi.org/10.4013/ctc.2019.121.12

25. Buriola AA, Vicente JB, Zurita RCM, Marcon SS. Overload of caregivers of children or adolescents suffering from mental disorder in the city of Maringá, Paraná. Esc Anna Nery. 2016;20(2):344-51. https://doi.org/10.5935/1414-8145.20160047

26. Eloia SC, Oliveira EM, Lopes MVO, Parente JRF, Eloia SMC, Lima DS. Sobrecarga de cuidadores familiares de pessoas com transtornos mentais: análise dos serviços de saúde. Ciênc Saúde Colet. 2018;23(9):3001-11. https://doi.org/10.1590/1413-81232018239.18252016

27. Bellini LC, Paiano M, Giacon BCC, Marcon SS. Psychiatric emergency hospitalization-meanings, feelings, perceptions and the family expectation. Rev Pesqui: Cuid Fundam. 2019;11(esp):383-9. https://doi.org/10.9789/2175-531.2019.v11i2.383-389

28. Borba LO, Maftum MA, Vayego SA, Mantovani MF, Felix JVC, Kalinke LP. Adherence of mental therapy for mental disorder patients to drug health treatment. Rev Esc Enferm USP. 2018;52:e03341. https://doi.org/10.1590/s1980-220x2017006603341

29. Mantovani LM, Ferretjans R, Marçal IM, Oliveira AM, Guimarães FC, Salgado JV. Family burden in schizophrenia: the influence of age of onset and negative symptoms. Trends Psychiatr Psychother. 2016;38(2):96-9. https://doi.org/10.1590/2237-6089-2015-0082

30. Faulkner S, Bee P. Perspectives on sleep, sleep problems, and their treatment, in people with serious mental illnesses: a systematic review. PloS One. 2016;11(9):e0163486. https://doi.org/10.1371/journal.pone.0163486

31. Sheaves B, Bebbington PE, Goodwin GM, Harrison PJ, Espie CA, Foster RG, et al. Insomnia and hallucinations in the general population: findings from the 2000 and 2007 British Psychiatric Morbidity surveys. Psychiatry Res. 2016;241:141-6. https://doi.org/10.1016/j. psychres.2016.03.055

32. Reeve S, Nickless A, Sheaves B, Freeman D. Insomnia, negative affect, and psychotic experiences: modelling pathways over time in a clinical observational study. Psychiatr Res. 2018;269:673-80. https://doi.org/10.1016/j.psychres.2018.08.090

33. Kasanova Z, Hajdúk M, Thewissen V, Myin-Germeys I. Temporal associations between sleep quality and paranoia across the paranoia continuum: an experience sampling study. J Abnorm Psychol. 2019;129(1):122-30. https://doi.org/10.1037/abn0000453

34. Schennach R, Feige B, Riemann D, Heuser J, Voderholzer U. Pre-to post-inpatient treatment of subjective sleep quality in 5,481 patients with mental disorders: a longitudinal analysis. J Sleep Res. 2019;28(4):e12842. https://doi.org/10.1111/jsr.12842

35. Perlis ML, Grandner MA, Chakravorty S, Bernert RA, Brown GK, Thase ME. Suicide and sleep: is it a bad thing to be awake when reason sleeps? Sleep Med Rev. 2016;29:101-7. https://doi.org/10.1016/j.smrv.2015.10.003

36. McCurry SM, Song Y, Martin JL. Sleep in caregivers: what we know and what we need to learn. Curr Op Psychiatr. 2015;28(6):497-503. https:// doi.org/10.1097/YCO.0000000000000205

37. Byun E, Lerdal A, Gay CL, Lee KA. How adult caregiving impacts sleep: a systematic review. Curr Sleep Med Rep. 2016;2(4):191-205. https:// doi.org/10.1007/s40675-016-0058-8

38. Peng HL, Lorenz RA, Chang YP. Factors associated with sleep in family caregivers of individuals with dementia. Perspect Psychiatric Care. 2018;55(1):95-102. https://doi.org/10.1111/ppc.12307

39. Freeman D, Sheaves B, Waite F, Harvey AG, Harrison PJ. Sleep disturbance and psychiatric disorders. Lancet Psychiatr. 2020;7(7):628-37. https://doi.org/10.1016/S2215-0366(20)30136-X

40. Arantes DJ, Picasso R, Silva EA. Grupos psicoeducativos com familiares dos usuários de um Centro de Atenção Psicossocial. Pesqui Prát Psicossoc [Internet]. 2019 [cited 2020 Aug 25];14(2):1-15. Available from: http://pepsic.bvsalud.org/pdf/ppp/v14n2/06.pdf 